\title{
Intended and Unintended Consequences of Prison Reform
}

\author{
Richard T. Boylan* \\ Rice University \\ Naci Mocan \\ Louisiana State University, NBER \& IZA
}

\begin{abstract}
The United States Supreme Court ruled in May 2011 that prison overcrowding in California constituted cruel and unusual punishment. This decision revived a long-standing debate among scholars and policy makers as to whether courts should intervene to protect the well-being of the disfranchised, by forcing states to improve schools, prisons, and mental institutions. We use data that span 1951-2006 to examine the impact of federal court orders condemning prison crowding, and the impact of states' releases from these court orders. We find that these interventions are associated with lower inmate mortality rates and fewer prisoners per capita. Correctional expenditures increase and welfare cash expenditures decrease while states are under court order, suggesting that the burden of improved prison conditions is borne by welfare recipients. Furthermore, states do not alter correctional spending and welfare cash payments spending after their release from court order, making the original changes in spending permanent. (JEL H7, I38, K4)
\end{abstract}

\section{Introduction}

Courts can be influential in protecting the well-being of the disfranchised segments of the population by forcing states to improve schools, prisons, and mental institutions. A recent example is the May 2011 decision of the Supreme Court, which declared that prison overcrowding in California constituted cruel and unusual punishment, and ordered California to reduce its prison population by 46,000 inmates. The division among the Supreme Court justices on this case is indicative of the disagreement over the merits of court intervention in state institutions. For example, while

\footnotetext{
*Email: rboylan@rice.edu

We would like to thank Duha Altindag for excellent research assistance. Jonah Rockoff, Francesco Drago, Christian Traxler, JJ Prescott, and seminar participants at Rice University, the 2009 NBER Summer Institute, the First Bonn \& Paris Workshop on Law and Economics, the 2009 Conference on Empirical Legal Studies, the 2010 American Economic Association Meetings in Atlanta, the 2010 American Law and Economics Association Meetings in Princeton, the first Annual Conference of the Spanish Association of Law and Economics in Madrid, and the 2010 Conference of the Association for Public Economic Theory in Istanbul provided valuable comments.
}

The Journal of Law, Economics, and Organization, Vol. 0, No. 0 doi:10.1093/jleo/ewt006 
court interventions have been criticized as undemocratic (Sandler and Schoenbrod 2004), others have argued that the disadvantaged should receive judicial help to balance out their lack of influence in the state political process (Rose-Ackerman 2003).

There exists evidence showing that judicial intervention has reduced inequality in education spending (Murray et al. 1998; Card and Payne 2002; Baicker and Gordon 2006). There is, however, also evidence underlining the limitations in the ability of the courts to influence resource reallocation in education spending. For example, Wood and Theobald (2003) find that judicial mandates that target equity in funding between school districts are successful only if the political and social values of the citizens are aligned with the intent of the court order. ${ }^{1}$

Similarly, it is unclear whether courts have improved prison conditions (Harriman and Straussman 1983; Taggart 1989; and Fliter 1996). ${ }^{2}$ This is not surprising as the judicial process is expected to be ineffective in reforming prisons and mental hospitals, because most state judges are elected for short terms. As a result, they are expected to put less weight on the welfare of individuals who are not allowed to vote (such as prisoners and individuals who are deemed incompetent to vote). Federal judges, on the other hand, are appointed for life and thus can force massive prison releases without facing negative personal consequences. The political insulation of federal judges can explain the recent court order to release inmates from California state prisons, Brown v. Plata, 563 US 1910 (2011).

It should be noted that Federal courts are limited by the Eleventh Amendment of the US constitution, which provides states with immunity in federal court. For instance, in 1973, the US Supreme Court reversed a US district court school equalization order, effectively removing federal courts from school finance litigation, San Antonio Independent School District v. Rodriguez, 411 US 1 (1973). To get around the Eleventh Amendment, federal cases name specific state officials as defendants, rather than the state; nonetheless, it is difficult to enforce court orders that require additional spending against state officials since most state constitutions forbid disbursements from the state treasury except by legislative appropriation (Hirschhorn 1984). For instance, in response to recent court orders, the California Assembly passed a bill to build additional facilities but did not allocate any additional funds. ${ }^{3}$ If state governments are reluctant to appropriate the necessary funds to improve the quality of the services provided by prisons and mental institutions, the federal courts

1. They summarize this finding by writing that "In the words of Alexander Hamilton, courts lack control of either the 'sword or the purse,' and are limited in their ability to affect significant social change."

2. However, there is evidence indicating that court orders reduced prison population growth (Levitt 1996).

3. Similarly, the Supreme Court of Alabama held that school funding violated the rights of school-aged children, but that it was powerless to fashion a remedy because of the separation of powers clause of the Alabama constitution (Roth 2003). 
can respond by closing these institutions, but judges may be unwilling to take such drastic measures. Furthermore, orders to close institutions may be reversed on appeal (Hirschhorn 1984). Consequently, federal judges can increase state spending only through suasion. Thus, one expects courts to be most effective in increasing state spending when the disfranchised have greater support from voters, elected officials, the federal bureaucracy, or interest groups (Schlanger 1999; Wood and Theobald 2003).

When courts are effective in increasing spending on prisoners, the legislature has to increase taxes or cut spending in other programs, given states' balanced budget requirements. The limited number of studies that analyzed states' responses to court decrees suggests that legislatures cut welfare spending to finance mandated increases in Medicaid and education spending (Baicker 2001; Baicker and Gordon 2006). Thus, we expect any increase in spending on prisons to come at the expense of welfare spending. In the California prison litigation case, the courts became aware of these tradeoffs. The panel of judges decreed that (Plata v. Schwarzenegger, No. CIV S-90-0520 LKK JFM P, 2009 WL 2430820, E.D. Cal. August 4, 2009):

During the pendency of this proceeding, the outlook for California's prisons has only grown dimmer. The state is now in the throes of a fiscal crisis that renders it unable or unwilling to commit the necessary resources to fix the problems in its prisons. [...] California has reduced spending on education, health care, the social safety net, and services for the needy, the blind, and children to the breaking point. Under these circumstances, we would be reluctant to direct the state to allocate additional funds to its prisons or to rehabilitative services at the expense of others to whom it has a legal and moral obligation.

Judicial intervention is expected to have been effective in the 1970s when prison rights were supported by the National Association for the Advancement of Colored People (NAACP), the Legal Services Corporation, the US Department of Justice, and the National Prison Project (Schlanger 1999, 2006). The extent of such support has declined since the late 1970s. ${ }^{4}$ Therefore, we expect courts to have been less effective in increasing prison spending since the late 1970s.

In this article, we examine the impact of federal court orders to improve prison conditions. Since 1970, federal court interventions have affected such dimensions of prison operations as staffing, the amount of space per inmate, medical and mental health care, food, hygiene, sanitation, disciplinary procedures, conditions in disciplinary segregation, exercise,

4. The NAACP ended its involvement in prison litigation in 1977, the Legal Services Corporation cut back on prison litigation during the Reagan years, the Justice Department stopped initiation of new prisoner conditions lawsuits during the Reagan administration, and foundation support for the National Prison Project was cut in the 1990s. 
fire safety, inmate classification, grievance policies, race discrimination, sex discrimination, religious discrimination and accommodations, and disability discrimination and accommodations (Schlanger 2006). In 1995, state attorneys general successfully lobbied Congress to pass the Prison Litigation Reform Act (PLRA) so that they could regain control over prisons (Wharton 1996). The PLRA ended federal court supervision over several state correctional systems and made any further court intervention more difficult (Schlanger 2006). Sullivan (2000) reports the deterioration of Tennessee prisons after their release from federal court supervision. ${ }^{5}$ Nonetheless, courts still order states to increase state correctional expenditures or reduce prison population, the most recent example being the case of the California prison system, which went all the way to the Supreme Court as mentioned earlier.

We find that following federal court orders, prison conditions improved and prison costs per inmate increased. Federal court orders to improve prison conditions are expected to reduce the deterrent effect of imprisonment, ${ }^{6}$ and some research suggests that outlays on social welfare and education could be substitutes for corrections in combating crime. ${ }^{7}$ Thus, if states seek to deter crime, an increase in state spending on social welfare and/or education following federal court intervention could be a vehicle (albeit a long-run vehicle) through which this goal can be achieved.

Our results, however, show that the court orders, which are associated with an increase in correctional spending, did not alter education spending, but generated a decrease in welfare cash assistance. Thus, our results indicate that federal courts can increase state expenditures but that the resources used to finance these additional expenditures come from other disadvantaged groups. We also find that states do not increase their welfare cash expenditures after having been released from the court order, making the original change in welfare spending permanent.

5. Specifically, Wharton (1996) underlines the decrease in the correctional staff and increase in the number of violations of regulations governing mental health, fire safety, occupational safety, and hazardous materials.

6. This is because, we find evidence in this article that court intervention reduces prison deaths, and Katz et al. (2003) show that a reduction in prison death rates leads to higher crime rates. Thus, an improvement in prison conditions through court intervention implies a reduction in deterrence. Furthermore, we document in this article that court orders reduce per capita prisoners in the state. Levitt (1996) shows that court orders impact the growth of prison population, which in turn influences the crime rate. Similarly, Drago et al. (2009) provide evidence that the Collective Clemency Bill passed by the Italian Parliament increased crime. Thus, the reduction in prison population due to court intervention is another avenue through which the court interventions may have reduced deterrence.

7. For instance, Donohue and Siegelman (1998) argue for the effectiveness of preschool and early childhood education, family-based therapy, and job training as a crime control device although empirical evidence for the effectiveness of such programs is scant at best. Corman and Mocan (2000, 2005), Mocan and Bali (2010), Gould et al. (2002), and Lin (2008) provide evidence that local unemployment, wages, and poverty have an impact on criminal activity, implying that education and training help combat crime. Lochner and Morettti (2004) demonstrate the impact of education on criminal activity. 
Section 2 discusses prison litigation. Section 3 describes the data. Section 4 explains our empirical methodology and Section 5 presents the results and the robustness analysis. Section 6 is the conclusion.

\section{Background and Prior Research}

Prior to the 1960s, federal and state courts almost invariably refused to hear cases regarding prison conditions (Bleich 1989; Schlanger 1999). In 1963, the Supreme Court held that inmates could employ the writ of Habeas corpus to contest their conditions of incarceration, Jones $v$. Cunningham, 371 US 236 (1963). Nonetheless, during the mid to late 1960 s, courts intervened on narrow issues. For instance, the courts prohibited guards from using two torture devices on prisoners (the crank telephone and the teeter board) and "the application of any whipping to the bare skin of prisoners," Jackson v. Bishop, E.D. Ark., 268 F. Supp. 804 (1967). In the 1970s, the federal courts took a much more activist stand. The prison systems in several states were ruled unconstitutional, and the courts enacted sweeping remedies based on the totality of prison conditions. Federal court intervention narrowed in scope in the 1980s, because inmates had fewer resources to litigate complex cases, and the federal judiciary was less sympathetic toward complex inmate litigation (Schlanger 1999, 2006; Piehl and Schlanger 2004). Specifically, legal support for inmate litigation eroded: the NAACP ended its work in prison litigation in 1977; Federal legal aid cut back on its prison litigation during the 1980s; foundation support for the National Prison Project was cut in the 1990s. Federal judges appointed in the 1980s by President Reagan were less supportive of inmate litigation. The US Department of Justice became less supportive of prison litigation during the Reagan administration and even switched sides in a number of its ongoing litigations. Finally, in 1995, Congress passed the PLRA that made existing court orders harder to sustain and new ones harder to obtain.

Three previous studies have examined the impact of court orders on prison conditions. Harriman and Straussman (1983), Taggart (1989), and Fliter (1996) provide contradictory evidence on whether court orders have influenced state spending on correctional facilities. These studies limited their analyses to total corrections expenditures and thus did not examine the impact of federal intervention on the number of state prisoners, corrections expenditures per prisoner, or corrections expenditures per capita. Furthermore, these earlier studies did not employ panel data, and instead examined corrections expenditures one state at the time, for the states in which the federal courts intervened. Thus, the observed increase in corrections expenditures in the litigated states may have been caused by overall national trends in corrections expenditures. In contrast, Levitt (1996) examined a panel of all states for the years 1972 through 1993 and court orders that span the years 1971 through 1992. He reported that prison litigation had a short-run effect on the growth rate of prison population. 


\section{Data}

Following Levitt (1996), we consider a state under court order if all correctional facilities of the state came under court order. Unlike Levitt, we restrict ourselves to federal court orders since we are interested in whether federal courts can improve state institutions. The Eleventh Amendment does not limit state courts, and the ability of the state courts to improve state institutions has already been established by Murray et al. (1998).

The "Litigated States" in our analysis, the date in which their correctional system came under court order, and the date of release are displayed in Table 1. We used the information at the Civil Rights Litigation Clearinghouse to reconcile the small discrepancies in year and litigated status among the prior studies (Taggart 1989; Fliter 1996; Levitt 1996). ${ }^{8}$ In Section 5.2, we report that our main results hold when we employ the states and dates in Levitt (1996).

We investigate the impact of court orders on prison spending, prison mortality, welfare expenditures, education expenditures, transportation expenditures, other state expenditures as well as local jail expenditures. This last variable is employed to investigate the extent to which states shift prisoners to jails to comply with the court orders. ${ }^{9}$

We define two welfare expenditure variables. The first one, "Cash," measures cash assistance to individuals. It includes all state expenditures on cash programs as well as Aid to Families with Dependent Children/ Temporary Assistance for Needy Families (AFDC/TANF) and assistance programs not under federal categorical programs (e.g., general assistance, refugee assistance, home relief, and emergency relief). The second variable, "Welfare - Cash," includes medical vendor payment benefits to individuals through Medicaid, state children's health insurance program, administration of medical and cash assistance, general relief, vendor, nursing homes, and welfare institutions owned and operated by a government. Thus, the welfare expenditure measures include the amount contributed by the state and federal matches.

Since we are interested in the effect of court intervention on yearly cost of incarceration, we examine corrections operating expenditures. ${ }^{10} \mathrm{We}$ also analyze the reaction of corrections capital outlays to court orders. Data for state financial variables are obtained from US Census Bureau,

8. http://clearinghouse.wustl.edu. The correct data for when the state Alabama was released from court order are obtained from "U.S. Relinquishes Alabama Prisons; Dismissing 17-Year Lawsuit," New York Times, January 15, 1989, p. 17.

9. We refer to "prison" or "corrections" as places of confinement of persons held in custody by the state government. We refer to "jails" as places of confinement of persons held in custody by the local government.

10. In 1992, more than three-quarters of the operating expenditures went to labor compensation (salaries, wages, and benefits), whereas the rest was devoted to the purchase of supplies, contract services, and the like. (Alexis M. Herman and Katharine G. Abraham, Measuring State and Local Government Labor Productivity: Examples from Eleven Services, US Department of Labor, June 1998.) 
Table 1. States Subject to Federal Court Intervention - "Litigated States"

\begin{tabular}{lllll}
\hline State & Case & Citation & $\begin{array}{l}\text { Year of } \\
\text { court } \\
\text { decision }\end{array}$ & $\begin{array}{l}\text { Year of } \\
\text { release }\end{array}$ \\
\hline AL & Pugh v. Locke & Injunction (M.D. Ala.) & 1975 & 1989 \\
AR & Holt v. Sarver & 300 F. Supp. 825 (E.D. Ark) & 1970 & 1982 \\
FL & Costello v. Wainwright & 489 F.Supp. 1100 (M.D. Fl.) & 1980 & 1993 \\
LA & Williams v. Edwards & Injunction (M.D. La.) & 1975 & 1997 \\
MS & Gates v. Collier & 349 F. Supp. 881 (N.D. Miss.) & 1972 & 1998 \\
NM & Duran v. Apodaca & Consent decree (D. N.M.) & 1980 & 1998 \\
NH & Laaman v. Helgemoe & 437 F.Supp. 269 (D.N.H.) & 1977 & 2001 \\
OK & Battle v. Anderson & 376 F. Supp. 402 (E.D. Ok.) & 1974 & 1986 \\
RI & Palmigiano v. Garrahy & 443 F. Supp. 956 (D. R.I.) & 1977 & 1995 \\
SC & Nelson v. Leeke & Consent decree (D. S.C.) & 1985 & 1996 \\
TN & Grubbs v. Bradley & 552 F. Supp. 1052 (M.D. Tenn.) & 1982 & 1996 \\
TX & Ruiz v. Estelle & 503 F. Supp. 1265 (S.D. Tex.) & 1980 & 2002 \\
\hline
\end{tabular}

Annual Survey of State Government Finances, and Census of Governments. All financial variables are converted in real (2007) dollars using the consumer price index.

We follow Katz et al. (2003) in using prison deaths as a proxy for prison conditions. Courts have used prison deaths as a proxy for prison conditions as recently as the May 2011 Supreme Court decision on prison conditions in California, Brown v. Plata, 563 US (2011). The prison mortality rate is computed as prison deaths per 1000 state prisoners. Due to data limitations, the prison mortality is not adjusted for age, gender, or race of prisoners. Data on prison population and prison deaths are obtained from Donohue and Wolfers (2005) and updated using data from the Bureau of Justice Statistics. ${ }^{11}$

We also control for real-income per capita, state unemployment rate, percentage of the state population that is black, percentage of the state population residing in urban areas, and variables gaging the age distribution in the state. Income per capita data are obtained from the Bureau of Economic Analysis. The unemployment rate is defined as the insured unemployment rate. ${ }^{12}$ The state and year-specific age and race distribution are calculated using information from the Center for Disease Control and the Bureau of the Census. The proportion of state population residing in urban areas is calculated using census data.

Table 2 presents summary statistics for the years. Most dependent variables cover the period 1951 through 2006. The average real spending is

11. The data can be downloaded at http://bpp.wharton.upenn.edu/jwolfers/DeathPen alty.shtml.

12. The data for the years 1960-2000 are obtained from Donohue and Wolfers (2005). The values for 2001-06 are calculated using state-specific weekly unemployment insurance claims information obtained from the US Department of Labor. 
Table 2. Summary Statistics

\begin{tabular}{lllll}
\hline Variable & $n$ & Mean $(\mathrm{SD})$ & Min. & Max. \\
\hline Oper. Corr. Exp./Inmate & 2660 & $\$ 31,084(\$ 17,503)$ & $\$ 2361$ & $\$ 145,744$ \\
Corr. Capital Exp./Inmate & 2305 & $\$ 4,258(\$ 6,113)$ & $\$ 0$ & $\$ 77,285$ \\
Deaths/inmate $(\times 1000)$ & 2713 & $3.06(1.98)$ & 0.00 & 26.06 \\
Inmates/capita $(\times 1000)$ & 2756 & $1.93(1.54)$ & 0.20 & 8.91 \\
Jail Exp./capita $(\times 1000)$ & 1496 & $\$ 32.86(\$ 28.27)$ & $\$ 0.001$ & $\$ 153.01$ \\
General revenue/capita & 2830 & $\$ 2,781(\$ 1,978)$ & $\$ 367$ & $\$ 26,680$ \\
State corrections exp./capita & 2782 & $\$ 67(\$ 60)$ & $\$ 3$ & $\$ 452$ \\
State cash/capita & 2782 & $\$ 126(\$ 90)$ & $\$ 7$ & $\$ 799$ \\
State (welfare-cash)/capita & 2782 & $\$ 600(\$ 481)$ & $\$ 41$ & $\$ 2,490$ \\
State education exp./capita & 2782 & $\$ 988(\$ 560)$ & $\$ 66$ & $\$ 4,167$ \\
State transportation exp./capita & 2782 & $\$ 396(\$ 235)$ & $\$ 79$ & $\$ 2,945$ \\
State other exp./capita & 2782 & $\$ 570(\$ 635)$ & $\$ 34$ & $\$ 8,759$ \\
Court order & 2830 & $0.08(0.27)$ & 0.00 & 1.00 \\
Income/capita & 2830 & $\$ 23,871(\$ 8,166)$ & $\$ 6,582$ & $\$ 52,933$ \\
Unemployment rate & 2830 & $3.07(1.63)$ & 0.50 & 12.60 \\
Black population (\%) & 2830 & $9.4(9.7)$ & 0.04 & 45.3 \\
Urban population (\%) & 2830 & $66.7(15.65)$ & 24.78 & 100.00 \\
Population aged 15-24 (\%) & 2830 & $15.8(2.2)$ & 9.1 & 21.5 \\
Population aged 25-44 (\%) & 2830 & $27.7(3.3)$ & 15.9 & 39.0 \\
Population aged 45-54 (\%) & 2830 & $11.4(2.3)$ & 7.4 & 42.6 \\
Population aged 55 or more $(\%)$ & 2830 & $19.5(3.3)$ & 6.4 & 28.8 \\
\hline
\end{tabular}

Notes: All monetary values are in real dollars. Most dependent variables cover years 1951-2006.

about $\$ 31,000$ per prisoner for operating expenditures and about $\$ 4,250$ for capital expenditures. Average inmate population ratio is about 2/1000 residents, and average prison death rate is about 3 deaths/1000 inmates, which translates into 27 deaths per year for the average state.

\section{Empirical Methodology}

In Figure 1, we display the ratio of corrections expenditures in litigated states to corrections expenditures in nonlitigated states. To account for differences in wealth among states, expenditures are normalized by state income per capita, and they are deflated by the number of inmates and state population. The behavior of this ratio as a function of the timing of the court order is informative. The horizontal axis displays the time periods (in years) relative to the year in which the court order was issued to the litigated state. For example, 4 years prior to the court order, litigated states spent about $72 \%$ per inmate of what was spent by the nonlitigated states. When the time period is zero (the year in which the court order was issued), the ratio jumps to about $87 \%$; it reaches $102 \% 2$ years after the court order and levels off. Thus, Figure 1 suggests that court intervention leads to higher corrections expenditures per inmate.

An ideal strategy to identify the impact of the court orders, however, would involve randomly assigning court orders to states and observing the 


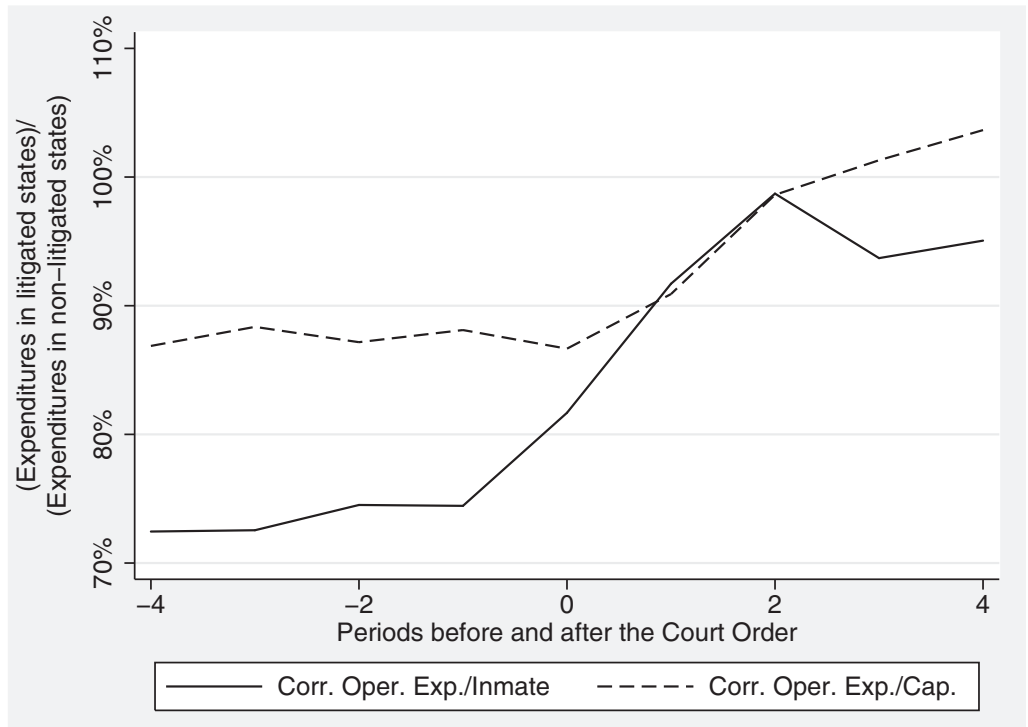

Figure 1. Corrections Operating Expenditures in Litigated States as a Percentage of Corrections Operating Expenditures in Non-Litigated States (all expenditures are normalized by income per capita).

differences in outcomes between states that received these court orders and states that did not. In fact, the 8 out of 12 litigated states are in the south, and thus the assignment of court orders is far from random. In the absence of such an experiment, we follow Biderman et al. (2010), Angrist and Lavy (2001), Ashenfelter and Card (1985), and Freeman (1984) in assuming that while there are differences between states that received and did not receive court orders, these differences are fixed over time (after controlling for income per capita). Furthermore, the courts do not react to short-term variations in prison conditions when imposing the court orders. Specifically, court orders are not issued in reaction to transitory deteriorations in prison conditions; rather prison litigation and court orders emerge in reaction to prison conditions that would remain dire if it were not for court intervention. The graph in Figure 1 supports this statement. There is no drop in per inmate corrections spending in litigated states relative to nonlitigated states before a court order was issued. ${ }^{13}$ Levitt (1996) provides evidence that states start responding to prison litigation before the court decision, specifically they start responding when the lawsuit is filed. The evidence in Figure 1 is consistent with this hypothesis, as corrections operating expenses per inmate increase slightly before the court order is imposed. Thus, the difference in corrections

13. Put differently, there is no indication of an "Ashenfelter dip." 
expenditures per inmate before and after the court order may somewhat underestimate the effect of the court intervention. ${ }^{14}$

In this spirit, we utilize a difference-in-difference methodology to examine how states react to court intervention. In particular, we investigate the impact of court intervention on various outcomes described earlier by estimating reduced-form regressions depicted by equation (1):

$$
Y_{i t}=\alpha_{i}+\beta_{i t}+\theta_{t}+\gamma X_{i t}+\eta \text { CourtOrder }_{i t}+\delta \text { CourtOrder }_{i t} \times \text { Post }_{80}+\varepsilon_{i t},
$$

where the dependent variable $Y_{\text {it }}$ stands for corrections expenditures (operating or capital outlays) per prisoner, the death rate for prisoners, and prisoners per capita. These dependent variables are employed to investigate the impact of court orders on corrections expenditures and prison conditions. To analyze the extent to which states shift prisoners from state correctional facilities to local jails in reaction to federal court orders, we employ per capita local jail expenditures as an additional dependent variable. Other dependent variables include per capita state revenues, per capita expenditures on corrections, per capita state cash assistance payments, per capita expenditures welfare minus cash assistance, per capita expenditures on education, per capita transportation expenditures, and per capita expenditures on other items (such as administrative expenditures). These individual expenditure items exhaust total state revenue.

The vector $X_{\text {it }}$ contains observable state characteristics as described in the data section above; $\alpha_{i}$ stands for unobserved state characteristic and $\theta_{t}$ represents year effects. The models also contain state-specific quadratic time trends, represented by $\beta_{\mathrm{it}}$. "CourtOrder ${ }_{\mathrm{it}}$ " is an indicator variable, which takes the value of one if state $i$ is under the court order in time $t$ and zero otherwise. "CourtOrder" can take the value of one only in litigated states, but there is variation in exposure to the "treatment" by a court order among litigated states; that is, in some states, the court order remained effective for longer periods than others. For example, Table 1 shows that the duration of a court order was from 1975 to 1997 in Louisiana, but it was from 1970 to 1982 in Arkansas. In order to account for the narrowing on federal court intervention since the 1980s, we create a dummy variable that is equal to one after 1980 (Post-1980) and interact it with CourtOrder. Thus, the impact of court order after 1980 is $\eta+\delta$, where we expect $\delta<0$ when $\eta>0$. In Section 5.2, we discuss the results obtained

14. Note that corrections operating expenditures per capita in litigated states (the dashed line in Figure 1) remain steady in comparison to nonlitigated states until 1 year after the court order (period 1 on the horizontal axis), whereas corrections operating expenditures per inmate rise sharply in the year in which the court order is handed out (period zero on the horizontal axis). This picture is consistent with the empirical result we report below, which shows that prisoners per capita in the state declines in reaction to a court order. It seems to indicate that the immediate reaction of the state to a court order is to adjust the prison population, whereas a budget increase in corrections spending takes a year to implement, possibly because of the fiscal cycle of the state. 
from different models for the impact of court orders, different subsets of data sets, and different control variables.

Although the model depicted by equation (1) analyzes the impact of a court order on the outcomes of interest, a question of independent interest is the impact of a release from a court order. For example, while it is important to investigate whether the imposition of a court order increases prison spending and decreases spending on welfare programs, it is equally important to analyze if the effect of a release from court order is symmetric. More specifically, equation (2) below is used to investigate the impact of a release, conditional on being under a court order:

$$
Y_{\mathrm{it}}=\kappa_{i}+\pi_{\mathrm{it}}+\tau_{t}+\lambda X_{\mathrm{it}}+\mu \text { Release }_{\mathrm{it}}+\omega_{\mathrm{it}},
$$

where Release is a dichotomous variable that takes the value of one in the year during which the state was released from court order as well as in all years afterward until the end of the sample. Thus, the variable Release captures the "treatment period" for the state in which the "treatment" is the release from a court order. ${ }^{15}$

Equation (2) is estimated in the sample of litigated states and in the years following the initiation of a court order. More precisely, this sample includes all state-years after a state came under the court order. ${ }^{16}$ For example, Table 1 shows that Alabama came under court order in 1975. Therefore, the sample includes the observations from Alabama in years 1975 and later. The same argument applies to the other states listed in Table 1. Thus, equation (2) investigates whether the release from the court order had an impact on outcomes (conditional on being under the court order). Most models are estimated in the sample that spans 1951-2006.

\section{Results}

\subsection{Main Specifications}

Tables 3 and 4 display the results obtained by estimating equation (1). The variables are in logarithms. Robust standard errors are clustered at the state level. The result reported in Column (1) of Table 3 indicates that, following court intervention, corrections operating expenditures per prisoner increase by about $27 \% .{ }^{17}$ Column (2) displays the results obtained from the model where the dependent variable is correctional capital outlays per prisoner. The estimated coefficient of CourtOrder indicates that being under the court order generates an increase in per inmate correctional capital outlays by $200 \%$ following the court intervention.

These estimates imply that corrections operating and capital expenditures go up by $\$ 175$ million for an average state. Court orders decrease the

15. In a different vein, Lutz (2011) analyzes the impact on school districts of being dismissed from court-ordered desegregation plans.

16. This specification does not include an interaction term with Post $_{80}$ because no state was released from a court order prior to 1980 .

17. The percentage impact is calculated as $\exp \left\{\beta-\frac{1}{2} \times \operatorname{Var}(\beta)\right\}-1$, see Kennedy (1981). 
Table 3. Impact of Federal Court Orders on Corrections

\begin{tabular}{|c|c|c|c|c|c|}
\hline & $\begin{array}{l}\text { (1) } \\
\text { Corrections } \\
\text { Oper. Exp. } \\
\text { per Inm. }\end{array}$ & $\begin{array}{l}\text { (2) } \\
\text { Corrections } \\
\text { Capital } \\
\text { Exp. per Inm. }\end{array}$ & $\begin{array}{l}\text { (3) } \\
\text { Deaths } \\
\text { per Inm. }\end{array}$ & $\begin{array}{l}\text { (4) } \\
\text { Inmates } \\
\text { per Cap. }\end{array}$ & $\begin{array}{l}\text { (5) } \\
\text { Jail } \\
\text { Exp./Cap. }\end{array}$ \\
\hline Court order & $\begin{array}{l}0.241^{\text {** }} \\
(0.049)\end{array}$ & $\begin{array}{l}1.129^{\star * \star} \\
(0.240)\end{array}$ & $\begin{array}{c}-0.220^{* *} \\
(0.095)\end{array}$ & $\begin{array}{l}-0.124^{* * *} \\
(0.037)\end{array}$ & $\begin{array}{c}0.014 \\
(0.122)\end{array}$ \\
\hline Court order $\times$ post $_{80}$ & $\begin{array}{r}-0.094^{*} \\
(0.054)\end{array}$ & $\begin{array}{l}-0.779^{* * *} \\
(0.280)\end{array}$ & $\begin{array}{c}0.212 \\
(0.151)\end{array}$ & $\begin{array}{l}0.123^{\star *} \\
(0.047)\end{array}$ & $\begin{array}{c}0.007 \\
(0.137)\end{array}$ \\
\hline Income/capita & $\begin{array}{c}0.396 \\
(0.255)\end{array}$ & $\begin{array}{l}5.190^{\star * \star} \\
(1.328)\end{array}$ & $\begin{array}{c}0.796 \\
(0.662)\end{array}$ & $\begin{array}{c}-0.084 \\
(0.178)\end{array}$ & $\begin{array}{l}2.151^{\star \star *} \\
(0.718)\end{array}$ \\
\hline Unemp. rate & $\begin{array}{c}0.005 \\
(0.036)\end{array}$ & $\begin{array}{c}0.145 \\
(0.181)\end{array}$ & $\begin{array}{c}-0.038 \\
(0.075)\end{array}$ & $\begin{array}{c}0.048 \\
(0.031)\end{array}$ & $\begin{array}{l}0.205^{\star *} \\
(0.077)\end{array}$ \\
\hline Black (\%) & $\begin{array}{c}0.212 \\
(0.138)\end{array}$ & $\begin{array}{c}-0.252 \\
(0.636)\end{array}$ & $\begin{array}{c}0.035 \\
(0.262)\end{array}$ & $\begin{array}{c}0.073 \\
(0.112)\end{array}$ & $\begin{array}{c}-0.376 \\
(0.380)\end{array}$ \\
\hline Urban (\%) & $\begin{array}{c}-0.994^{* * *} \\
(0.344)\end{array}$ & $\begin{array}{r}-0.636 \\
(1.468)\end{array}$ & $\begin{array}{c}0.401 \\
(0.410)\end{array}$ & $\begin{array}{l}1.011^{\star *} \\
(0.379)\end{array}$ & $\begin{array}{l}2.095^{\star *} \\
(0.832)\end{array}$ \\
\hline Population 15-24 (\%) & $\begin{array}{c}0.389 \\
(0.319)\end{array}$ & $\begin{array}{c}-0.673 \\
(1.598)\end{array}$ & $\begin{array}{c}0.275 \\
(0.655)\end{array}$ & $\begin{array}{r}-0.469^{*} \\
(0.249)\end{array}$ & $\begin{array}{c}0.050 \\
(0.655)\end{array}$ \\
\hline Population 25-44 (\%) & $\begin{array}{c}-0.486 \\
(0.912)\end{array}$ & $\begin{array}{c}-4.715 \\
(3.246)\end{array}$ & $\begin{array}{c}1.154 \\
(1.084)\end{array}$ & $\begin{array}{c}-0.304 \\
(0.591)\end{array}$ & $\begin{array}{r}3.689^{*} \\
(2.005)\end{array}$ \\
\hline Population 45-54 (\%) & $\begin{array}{c}-0.481 \\
(0.370)\end{array}$ & $\begin{array}{r}-2.315 \\
(1.875)\end{array}$ & $\begin{array}{c}0.443 \\
(0.523)\end{array}$ & $\begin{array}{c}-0.062 \\
(0.251)\end{array}$ & $\begin{array}{c}1.280 \\
(1.204)\end{array}$ \\
\hline Population 55 or more (\%) & $\begin{array}{c}-0.651 \\
(0.534) \\
\end{array}$ & $\begin{array}{c}-0.605 \\
(3.027) \\
\end{array}$ & $\begin{array}{c}0.849 \\
(0.873) \\
\end{array}$ & $\begin{array}{c}0.184 \\
(0.459) \\
\end{array}$ & $\begin{array}{c}-0.084 \\
(0.980) \\
\end{array}$ \\
\hline $\begin{array}{l}\text { Observations } \\
R^{2}\end{array}$ & $\begin{array}{l}2660 \\
0.956\end{array}$ & $\begin{array}{l}2301 \\
0.455\end{array}$ & $\begin{array}{l}2553 \\
0.441\end{array}$ & $\begin{array}{r}2756 \\
0.976\end{array}$ & $\begin{array}{r}1496 \\
0.947\end{array}$ \\
\hline
\end{tabular}

Notes: The dependent variables are natural logarithms of the corrections operating expenditures per inmate, corrections capital expenditures per inmate, prison deaths per 1000 inmates, prisoners per 1000 residents, and jail expenditures per capita, respectively, in Columns (1-5). All models contain state-fixed effects and year dummies as well as linear and quadratic state trends. Robust standard errors clustered at the state level are presented in parentheses. ${ }^{* \star *},{ }^{* \star}$, and ${ }^{*}$ indicate significance at 1,5 , and $10 \%$, respectively.

prison death rate by $20 \%$ as shown in Column (3), which translates into about six fewer deaths per year for an average state. The result in Column (4) indicates that court orders generate a $12 \%$ decline in prisoners per capita.

The coefficient of CourtOrder $\times \operatorname{Post}_{80}(\delta)$ is of the opposite sign of CourtOrder $(\eta)$ in all regressions with the exception of jail expenditures. We cannot reject the hypothesis that the sum of $\eta$ and $\delta$ is zero for corrections capital expenditures and inmates per capita. This result suggests that while court orders increased capital expenditures and reduced prison populations prior to 1980 , court orders had no significant impact on these outcomes after $1980 .{ }^{18}$ In Column (1), the sum of $\eta$ and $\delta$ is negative and significantly different from zero $(p=0.02)$, indicating that court orders had a smaller but still statistically significant impact on corrections operating expenditures per inmate after 1980. These findings are consistent

18. As explained in Section 5.2 below, considering the time period of Post-1981 or Post1985 generated the same results as the ones obtained from the one that includes Post-1980. 





with the hypothesis that post-1980, court orders narrowed in scope (Fliter 1996; Schlanger 2006).

A potential reaction of states to court orders could be to shift the prison population to local jails. Column (5) of Table 3 displays the results where per capita jail expenditures are used as dependent variable. There is no statistically significant impact of CourtOrder, indicating that jail expenditures do not change in reaction to court orders. We also used as dependent variables the number of jail inmates and the number of state prisoners held in local jails because of overcrowding (both measured per capita and in logs). Again, we found no statistically significant impact of CourtOrder on these variables, thus indicating that court orders do not lead to a shift of inmates from prisons to jails.

Given that court orders decrease prison population and improve prison conditions, as revealed by a decline in prison deaths and prison population, court orders effectively reduce deterrence. ${ }^{19}$ As described in the introduction, welfare spending may be a tool for short-term crime prevention as a substitute for other deterrence measures such as imprisonment and prison conditions. Spending on education is another potential but longer term vehicle through which crime commission can be influenced. Such an increase in welfare and/or education spending would dictate an increase in total state revenue. On the other hand, the increase in correction spending following the court order could prompt a re-allocation of expenditures between various spending categories. The results presented in Table 4 allow us to investigate the extent to which states re-allocate resources following the court orders.

In Table 4 per capita state revenues (in Column 1) and various spending categories of the state (Columns 2-7) are the dependent variables. These spending categories exhaust total state expenditures. Column (1) of Table 4 indicates that court orders have no impact on per capita state revenue. Consistent with earlier results, Column (2) shows that court orders increase per capita correctional spending by $24 \%$. In Column (3), the coefficient of CourtOrder is negative and statistically significant, indicating the unintended consequence of increasing correctional spending: court orders generate about a $22 \%$ reduction in per capita cash assistance. Columns (4) through (7) demonstrate that court orders have no impact on welfare - cash spending, education spending, transportation spending, or other state spending.

Taken together, the results displayed in Tables 3 and 4 demonstrate that court orders improved prison conditions, and they increased the cost of providing correctional services. Since state revenue did not change (see Column 1 of Table 4), states maintained a balanced budget by decreasing cash welfare spending. During our period of study (1951 through 2006), there were numerous changes in the federal rules that determine cash

19. In fact, Levitt (1996) has shown that the decrease in prison population due to court orders had a significant impact on state crime rates. 
payments. Thus, one may be concerned that our results are driven by correlation between prison litigation and changes in federal welfare rules. Our estimated dollar decrease in cash payments is larger than the dollar increase in corrections expenditures. However, the difference between the decrease in cash payments and corrections expenditures is not statistically significant. Furthermore, a larger response in cash payments is fully consistent with 1 to 1 re-allocation of funds from cash payments to corrections. The reason for this is that the census measure of AFDC/TANF includes expenditures financed by both the state and the federal government. In addition, under AFDC, the federal government matched state expenditures. Thus, a $\$ 1$ transfer in state resources from AFDC toward corrections could lead to a $\$ 1.80$ decrease in AFDC expenditures. In general, the hypothesis that our results are driven by a correlation between prison litigation and federal welfare rules is unlikely given that our results are robust over a large number of specifications.

To investigate the sensitivity of our results to model specification, we estimate the models without control variables. The results, reported in Tables 5 and 6 , indicate that neither the statistical significance nor the point estimate change appreciably when drop the control variables. As a further check of the validity of the identification strategy, we investigate the impact of exposure to court orders on different facets of the criminal justice system: police spending and jail spending. Specifically, we examine the impact of court orders on the difference between state correctional operating expenditures and (i) police expenditures and (ii) jail expenditures. If corrections expenditures and other criminal justice expenditures move in tandem in states that are exposed to court orders as well as in states that are not under the court order, this would imply that some unobserved factors confound the impact of court orders on corrections spending. Put differently, if federal intervention has an effect, the difference between corrections expenditures and other criminal justice expenditures is expected to get larger in states that are exposed to court orders. Thus, the triple-difference estimates allow us to control for unobserved factors that are not accounted for by state-fixed effects, year-fixed effects, state-specific time trends.

Table 7 displays the results of four specifications. In Columns (1) and (2), the dependent variables are the difference between per inmate (or per capita) corrections operating expenditures and per capita police spending. In Column (3), the dependent variable is the difference between corrections operating expenditures per inmate and jail expenditures per jail inmate. In Column (4), we report the results of the specification where the dependent variable is the difference between per capita corrections operating expenditures and per capita jail expenditures. The coefficient of CourtOrder is positive and statistically significant in all cases, indicating that the wedge between corrections operating expenditures and other correctional expenditures increased in states that were exposed to court orders in comparison to those states that were not. 
Table 5. Impact of Federal Court Orders on Corrections

\begin{tabular}{|c|c|c|c|c|c|}
\hline & $\begin{array}{l}(1) \\
\text { Corrections } \\
\text { Oper. Exp. } \\
\text { per Inm. }\end{array}$ & $\begin{array}{l}(2) \\
\text { Corrections } \\
\text { Capital Exp. } \\
\text { per Inm. }\end{array}$ & $\begin{array}{l}\text { (3) } \\
\text { Deaths } \\
\text { per Inm. }\end{array}$ & $\begin{array}{l}\text { (4) } \\
\text { Inmates } \\
\text { per Cap. }\end{array}$ & $\begin{array}{l}\text { (5) } \\
\text { Jail } \\
\text { Exp./Cap. }\end{array}$ \\
\hline Court order & $\begin{array}{l}0.232^{* * *} \\
(0.050)\end{array}$ & $\begin{array}{l}1.225^{\star * *} \\
(0.227)\end{array}$ & $\begin{array}{c}-0.192^{\star *} \\
(0.086)\end{array}$ & $\begin{array}{c}-0.116^{\star * \star} \\
(0.034)\end{array}$ & $\begin{array}{c}0.105 \\
(0.098)\end{array}$ \\
\hline CourtOrder $\times$ Post $_{80}$ & $\begin{array}{r}-0.050 \\
(0.062)\end{array}$ & $\begin{array}{c}-0.764^{\star \star \star} \\
(0.273)\end{array}$ & $\begin{array}{c}0.184 \\
(0.131)\end{array}$ & $\begin{array}{c}0.099^{\star \star} \\
(0.046)\end{array}$ & $\begin{array}{c}-0.011 \\
(0.124)\end{array}$ \\
\hline Observations & 2660 & 2301 & 2553 & 2756 & 1496 \\
\hline$R^{2}$ & 0.953 & 0.439 & 0.436 & 0.974 & 0.942 \\
\hline
\end{tabular}

Notes: The dependent variables are natural logarithms of the corrections operating expenditures per inmate, corrections capital expenditures per inmate, prison deaths per 1000 inmates, prisoners per 1000 residents, and jail expenditures per capita, respectively, in Columns (1-5). All models contain state-fixed effects and year dummies as well as linear and quadratic state trends. Robust standard errors clustered at the state level are presented in parentheses. ${ }^{* \star *},{ }^{* \star}$ and ${ }^{*}$ indicate significance at 1,5 , and $10 \%$, respectively.

Table 6. Impact of Federal Court orders on the State Spending

\begin{tabular}{|c|c|c|c|c|c|c|c|}
\hline & $\begin{array}{l}(1) \\
\text { General } \\
\text { Rev./Cap. }\end{array}$ & $\begin{array}{l}(2) \\
\text { Corrections } \\
\text { Exp./Cap }\end{array}$ & $\begin{array}{l}(3) \\
\text { Cash } \\
\text { per Cap. }\end{array}$ & $\begin{array}{l}(4) \\
\text { Welfare - Cash } \\
\text { per Cap. }\end{array}$ & $\begin{array}{l}(5) \\
\text { Educ. } \\
\text { Exp./Cap. }\end{array}$ & $\begin{array}{l}(6) \\
\text { Trans. } \\
\text { Exp./Cap. }\end{array}$ & $\begin{array}{l}(7) \\
\text { Other } \\
\text { Exp./Cap }\end{array}$ \\
\hline Court order & $\begin{array}{c}0.002 \\
(0.019)\end{array}$ & $\begin{array}{l}0.224^{\star \star \star} \\
(0.050)\end{array}$ & $\begin{array}{c}-0.274^{\star *} \\
(0.113)\end{array}$ & $\begin{array}{c}-0.007 \\
(0.040)\end{array}$ & $\begin{array}{c}-0.023 \\
(0.022)\end{array}$ & $\begin{array}{c}-0.012 \\
(0.039)\end{array}$ & $\begin{array}{c}0.046 \\
(0.053)\end{array}$ \\
\hline $\begin{array}{l}\text { CourtOrder } \times \\
\text { Post }_{80}\end{array}$ & $\begin{array}{c}-0.004 \\
(0.031)\end{array}$ & $\begin{array}{r}-0.050 \\
(0.051)\end{array}$ & $\begin{array}{c}0.158^{*} \\
(0.086)\end{array}$ & $\begin{array}{r}-0.023 \\
(0.053)\end{array}$ & $\begin{array}{c}0.031 \\
(0.038)\end{array}$ & $\begin{array}{c}0.035 \\
(0.052)\end{array}$ & $\begin{array}{r}-0.068 \\
(0.069)\end{array}$ \\
\hline $\begin{array}{l}\text { Observations } \\
R^{2}\end{array}$ & $\begin{array}{r}2830 \\
0.988\end{array}$ & $\begin{array}{l}2782 \\
0.970\end{array}$ & $\begin{array}{l}2782 \\
0.864\end{array}$ & $\begin{array}{l}2782 \\
0.987\end{array}$ & $\begin{array}{r}2782 \\
0.983\end{array}$ & $\begin{array}{r}2782 \\
0.977\end{array}$ & $\begin{array}{r}2782 \\
0.866\end{array}$ \\
\hline
\end{tabular}

Notes: The dependent variables are the natural logarithms of General state revenues per capita, total state corrections expenditure per capita, state cash payments per capita, state noncash welfare expenditures per capita, state education expenditures per capita, state transportation expenditures per capita and other state expenditures per capita, respectively, in Columns (1-7). All models contain state-fixed effects and year dummies as well as linear and quadratic state trends. Robust standard errors clustered at the state level are presented in parentheses. ${ }^{* * *},{ }^{* *}$ and ${ }^{*}$ indicate significance at 1,5 , and $10 \%$, respectively.

To investigate the impact of having been released from a court order, we estimated models depicted by equation (2). Tables 8 and 9 display the results. The sample sizes are smaller in these specifications because they analyze the impact of having been released from the court order, given that a court order was imposed. Since we have only 12 states that contribute to this identification, clustered robust standard errors underestimate standard errors. Thus, we follow Cameron et al. (2008) and provide bootstrapped $p$-values for the variable Release [in brackets]. Regardless of whether we compute $p$-value using limiting $p$-values or bootstrap, correction and cash payments spending do not change when states are released from court order. Thus, the budget cuts that are associated with cash payment programs following the court order are not restored after the state's release from court order. Similarly, states do not alter per inmate 
Table 7. Impact of Federal Court Orders on the Difference Between Corrections Operating Expenditures and Local Police and Jail Spending

\begin{tabular}{|c|c|c|c|c|}
\hline & \multicolumn{2}{|c|}{$\begin{array}{l}(1) \quad(2) \\
\text { Corrections: Police }\end{array}$} & \multicolumn{2}{|c|}{$\begin{array}{l}\text { (3) } \\
\text { Corrections: Jail }\end{array}$} \\
\hline & Version 1 & Version 2 & Version 1 & Version 2 \\
\hline CourtOrder & $\begin{array}{l}0.274^{\star \star *} \\
(0.053)\end{array}$ & $\begin{array}{l}0.231^{* * *} \\
(0.050)\end{array}$ & $\begin{array}{l}0.314^{\star * *} \\
(0.104)\end{array}$ & $\begin{array}{l}0.322^{\star \star *} \\
(0.093)\end{array}$ \\
\hline CourtOrder $\times$ Post $_{80}$ & $\begin{array}{l}-0.107^{\star *} \\
(0.052)\end{array}$ & $\begin{array}{c}-0.097 \\
(0.060)\end{array}$ & $\begin{array}{r}-0.206^{*} \\
(0.115)\end{array}$ & $\begin{array}{l}-0.206^{\star \star} \\
(0.102)\end{array}$ \\
\hline Income/capita & $\begin{array}{c}0.136 \\
(0.255)\end{array}$ & $\begin{array}{c}0.203 \\
(0.288)\end{array}$ & $\begin{array}{c}-0.395 \\
(0.537)\end{array}$ & $\begin{array}{c}-0.487 \\
(0.449)\end{array}$ \\
\hline Unemp. rate & $\begin{array}{r}-0.056 \\
(0.039)\end{array}$ & $\begin{array}{r}-0.006 \\
(0.048)\end{array}$ & $\begin{array}{c}-0.045 \\
(0.105)\end{array}$ & $\begin{array}{r}-0.142^{*} \\
(0.083)\end{array}$ \\
\hline Black (\%) & $\begin{array}{c}0.168 \\
(0.139)\end{array}$ & $\begin{array}{l}0.318^{\star \star} \\
(0.149)\end{array}$ & $\begin{array}{c}0.074 \\
(0.222)\end{array}$ & $\begin{array}{c}0.484 \\
(0.339)\end{array}$ \\
\hline Urban (\%) & $\begin{array}{l}-1.245^{\star \star} \\
(0.574)\end{array}$ & $\begin{array}{r}-0.495 \\
(0.451)\end{array}$ & $\begin{array}{c}-1.876^{\star *} \\
(0.732)\end{array}$ & $\begin{array}{l}-2.424^{\star * *} \\
(0.843)\end{array}$ \\
\hline Population 15-24 (\%) & $\begin{array}{r}0.620^{*} \\
(0.315)\end{array}$ & $\begin{array}{c}0.247 \\
(0.266)\end{array}$ & $\begin{array}{c}0.306 \\
(0.696)\end{array}$ & $\begin{array}{c}0.346 \\
(0.683)\end{array}$ \\
\hline Population 25-44 (\%) & $\begin{array}{c}-0.312 \\
(0.632)\end{array}$ & $\begin{array}{c}-0.707 \\
(0.786)\end{array}$ & $\begin{array}{c}-3.017^{\star \star} \\
(1.482)\end{array}$ & $\begin{array}{l}-4.409^{\star \star} \\
(2.009)\end{array}$ \\
\hline Population 45-54 (\%) & $\begin{array}{c}0.002 \\
(0.344)\end{array}$ & $\begin{array}{l}-0.922^{* *} \\
(0.407)\end{array}$ & $\begin{array}{l}-1.497^{* *} \\
(0.700)\end{array}$ & $\begin{array}{c}-1.931 \\
(1.273)\end{array}$ \\
\hline Population 55 or more (\%) & $\begin{array}{c}0.227 \\
(0.587)\end{array}$ & $\begin{array}{c}0.030 \\
(0.585)\end{array}$ & $\begin{array}{c}0.337 \\
(0.979)\end{array}$ & $\begin{array}{c}-0.034 \\
(1.059)\end{array}$ \\
\hline $\begin{array}{l}\text { Observations } \\
R^{2}\end{array}$ & $\begin{array}{r}2161 \\
0.931\end{array}$ & $\begin{array}{r}2248 \\
0.888\end{array}$ & $\begin{array}{r}1400 \\
0.811\end{array}$ & $\begin{array}{r}1482 \\
0.952\end{array}$ \\
\hline
\end{tabular}

Notes: The dependent variables are the differences between the natural logarithms of the following variables: (1) [Corrections Operating Expenditures/Inmate] - [Local Police Expenditures/Population], (2) [Corrections Operating Expenditures/Population]-[Local Police Expenditures/Population], (3) [Corrections Operating Expenditures/ Inmate]-[Jail Expenditures/Jail Inmates], and (4) [Corrections Operating Expenditures/Population] - [Jail Expenditures/Population]. All control variables are in natural logarithms. All models contain state-fixed effects and year dummies as well as linear and quadratic state trends. Robust standard errors clustered at the state level are presented in parentheses. ${ }^{* \star *},{ }^{* *}$ and ${ }^{*}$ indicate significance at 1,5 , and $10 \%$, respectively.

corrections spending when the court order is lifted, and prison deaths per inmate and inmates per capita do not change when states are released from the court order.

\subsection{Robustness}

To investigate the robustness of the results, we performed a number of analyses. First, we investigated whether the results were sensitive to the omission of Alaska and Hawaii. Alaska receives its tax revenues from oil, which is a highly variable revenue source. Hawaii is also unusual as a large percentage of its revenues comes from tourism. However, omitting these states did not alter the results. Second, we included in the models an indicator variable that identified the states that were sued in state courts for education spending. Controlling for this effect did not alter the estimated 
Table 8. Impact of Releases from Federal Court Orders on Corrections

\begin{tabular}{lccccc}
\hline & $(1)$ & $(2)$ & $(3)$ & $(4)$ & $(5)$ \\
& Corrections & Corrections & & & \\
& Oper. Exp. & Capital Exp. & Deaths & Inmates & Jail \\
& per Inm. & per Inm. & per Inm. & per Cap. & Exp./Cap. \\
& -0.047 & -0.130 & 0.020 & 0.006 & -0.026 \\
& $(0.053)$ & $(0.227)$ & $(0.144)$ & $(0.053)$ & $(0.061)$ \\
Release & {$[0.839]$} & {$[0.972]$} & {$[0.988]$} & {$[0.977]$} & {$[0.964]$} \\
& 0.768 & -2.347 & 0.524 & 0.258 & -0.107 \\
Income/capita & $(0.526)$ & $(3.140)$ & $(1.776)$ & $(0.663)$ & $(0.753)$ \\
& 0.066 & -0.294 & 0.360 & 0.079 & $0.157^{*}$ \\
Unemp. rate & $(0.056)$ & $(0.367)$ & $(0.216)$ & $(0.072)$ & $(0.072)$ \\
& 0.093 & 0.512 & 1.110 & -0.028 & 0.411 \\
Black (\%) & $(0.131)$ & $(0.980)$ & $(0.513)$ & $(0.098)$ & $(0.545)$ \\
& -1.747 & -2.840 & -0.780 & 3.796 & 2.034 \\
Urban (\%) & $(1.133)$ & $(7.938)$ & $(4.136)$ & $(1.223)$ & $(2.207)$ \\
& -0.369 & 1.969 & 1.072 & 0.110 & 2.508 \\
Population 15-24 (\%) & $(0.582)$ & $(4.837)$ & $(2.239)$ & $(0.464)$ & $(1.191)$ \\
& 0.694 & -6.170 & 2.806 & -1.832 & 2.867 \\
Population 25-44 (\%) & $(1.995)$ & $(6.527)$ & $(3.506)$ & $(1.048)$ & $(1.685)$ \\
& 0.241 & -1.053 & 0.933 & 0.694 & 3.022 \\
Population 45-54 (\%) & $(1.588)$ & $(6.485)$ & $(3.425)$ & $(1.610)$ & $(2.126)$ \\
& 0.779 & -1.147 & 7.497 & -3.748 & -4.912 \\
Population 55 or more (\%) & $(1.667)$ & $(7.343)$ & $(4.987)$ & $(2.115)$ & $(2.052)$ \\
\hline & 355 & 355 & 346 & 367 & 290 \\
\hline Observations & 0.966 & 0.642 & 0.466 & 0.988 & 0.951 \\
\hline$R^{2}$ & & & & & \\
\hline
\end{tabular}

Notes: The dependent variables are natural logarithms of the corrections operating expenditures per inmate, corrections capital expenditures per inmate, prison deaths per 1000 inmates, prisoners per 1000 residents, and jail expenditures per capita, respectively, in Columns (1-5). All models contain state-fixed effects and year dummies as well as linear and quadratic state trends. Robust standard errors clustered at the state level are presented in parentheses. The values in [brackets] are the p-values of the estimated coefficients of release based on bootstrapping proposed by Cameron et al. (2008).

coefficients or their statistical significance. Third, the results remained intact when we added to the models percent Democrats in state house and senate. Including the poverty rate as a regressor did not alter the results either. Fourth, we investigated whether the decrease in cash welfare following prison court orders is caused by changes in AFDC matching rates. Including the log of the AFDC matching rate as an additional regressor did not change the results. ${ }^{20}$ Similarly, adding dummy variables for the post-1996 period or for the periods of 1992-96 and post-1996 to adjust for the time period of the welfare reform did not influence the results. Fifth, we estimated the prison death equation using the level of (deaths per inmates) as the dependent variable, rather than its logarithm. About $4 \%$ of the sample contained zeros for this variable. Estimating the

20. Similarly, including the log of the Medicaid matching rates does not change the results for noncash welfare spending. 


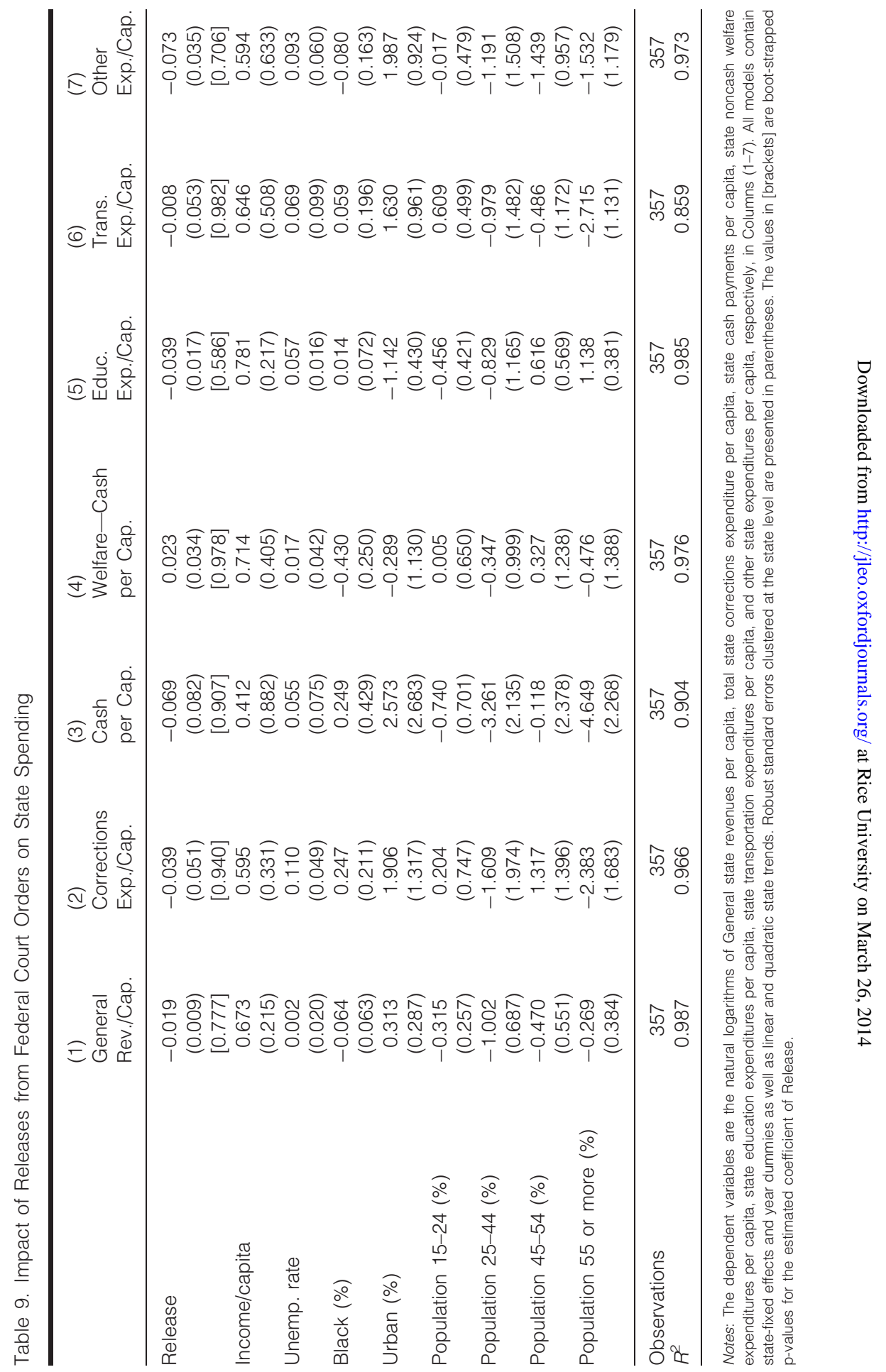


prison death rate regression in levels did not alter the results. The coefficient of CourtOrder was estimated as $-0.75(p=0.054)$, indicating that a court order reduces the prison death rate by $0.75 / 1000$ inmates, which implies a reduction of about eight deaths for an average state, which is similar to the results obtained from the model with logarithms.

States differ in many dimensions, ranging from culture to political climate, from the crime rate to the extent of poverty. As discussed above, adding control variables such as percent Democrats in the state senate and the poverty rate does not alter the results. Nonetheless, it is conceivable that even after controlling for these variables, states' reactions to court orders could be confounded with time-varying unobservables. Furthermore, states could be structurally different in their reactions to court orders. Although it is not feasible to estimate the models for each state separately, we tested the sensitivity of the results by dropping each state from the sample, one at a time, and re-estimating the models. The results did not change, indicating that they are not driven by outlier states. We also re-estimated the models using Southern states only. Estimating the models using this sample of 12 states generates similar results although the coefficients of capital expenditures and prison deaths became insignificant.

We also estimated the models depicted by equation (1) by replacing the dummy variable Post 80 with Post $_{81}$, where Post ${ }_{81}$ takes the value of one in the year of 1981 or later. This specification investigates whether court orders had a different impact after 1981. The results were almost identical to the ones presented in the article. When we replaced this variable with Post $_{85}$, where Post ${ }_{85}$ takes the value of one in 1985 or later, the results were very similar to those reported in Tables 3 and 4 (the only difference is that the impact of court order on prison deaths became statistically insignificant). Finally, when we used the final court decision dates listed in Levitt (1996), we obtained coefficients that were very similar both in magnitude and statistical significance. The only difference was that the coefficients of prison deaths and prison population became insignificant.

Throughout, we have assumed that litigation starts affecting states the year of the court order. Nonetheless, it is conceivable that states start changing policies when the suit is filed. ${ }^{21}$ Consistent with this hypothesis, Levitt (1996) finds that the prison population decreases right after court filings. Furthermore, in Figure 1, correctional expenditures appear to increase before the court order is actually imposed. Thus, CourtOrder may be a noisy proxy for when federal courts affect state prisons. This measurement error problem may lead us to underestimate the impact of federal courts on state prisons. To account for this source of inconsistency, we estimate the models in Table 3 with a set of dummy variables for the time between the year in which the litigation was filed and the year the court

21. In our sample, the time interval between the filing date and the court decision is on average 3.25 year long. 
order was imposed. ${ }^{22}$ For example, if 5 years have passed between the filing of the lawsuit and the year in which the court order was issued, we include five mutually exclusive dummy variables to control for the impact of these five prior years during which the state could have adjusted its reaction to the upcoming court decision. In these regressions, the litigation-to-court-order dummy variables are not significantly different from zero. Furthermore, the coefficients for CourtOrder are not significantly altered by the inclusion of these additional controls. ${ }^{23}$ Alternatively, we investigated states' reaction to court orders under the assumption that court orders are effective 1 year earlier. In other words, we moved the start date of court orders to the prior year in each litigated state. ${ }^{24}$ This exercise produced court order effects that are smaller in magnitude, but the statistical significance of the estimated coefficients is retained. ${ }^{25}$

Although the models control for a host of state attributes as well as state-specific trends, it could still be the case that state-specific unobservables may be correlated with court orders. To control for such an effect, we re-estimated the benchmark models reported in Table 3 with the inclusion of the lagged values of the dependent variables as additional regressors, and instrumented the lagged-dependent variable with its second lag. ${ }^{26}$ The basic inference did not change. The point estimates became smaller in absolute value although their statistical significance became stronger. $^{27}$

The impact of the court order may be changing over the duration of the court order. For example, the impact on prison conditions may be stronger during the first few years after the federal court issues the order and it may die out over time. To investigate this possibility, we created five dummy variables that identify the five time segments over the course of a court order. Specifically, the first variable takes the value of one during the first 5 years of the court order and zero elsewhere. The second variable is equal to one during the $6 \mathrm{th}, 7 \mathrm{th}, 8 \mathrm{th}, 9 \mathrm{th}$, and 10 th years of the court order; and the fifth dichotomous variable is equal to one during the

22. We include a maximum of eight dummy variables for each litigated state to capture up to 8 years prior to the court order.

23. The coefficient of CourtOrder (and its standard error) was $0.219(0.048)$ for operating expenditures. It was $1.246(0.259)$ for capital expenditures, $-0.233(0.102)$ for deaths per inmate, and $-0.096(0.113)$ for per capita jail expenditures.

24. For example, we moved the court order date to 1974 in case of AL, to 1969 in case of AR, and so on. See Table 1.

25. The coefficient of CourtOrder (and its standard error) became 0.164 (0.044) for operating expenditures. It was $0.997(0.217)$ for capital expenditures, $-0.165(0.095)$ for deaths per inmate, and $-0.033(0.103)$ for per capita jail expenditures. This result is not surprising to the extent that altering the actual date of the court order introduces measurement error in the explanatory variable and thus a downward bias in the estimates.

26. See Biderman et al. (2010) for a similar application.

27. When we used two lags of the dependent variables as additional regressor and instrumented them with lags three and four, the point estimates and their statistical significance were similar to those obtained from one-lag specifications. 
years of twenty-one and higher. ${ }^{28}$ The results obtained from this specification are presented in Tables 10 and 11. In Column (1) of Table 10, we observe that the impact of the court order on corrections operating expenditures is rising over time and then declining, with the biggest impact being observed during the years of 6-10 (during 2nd 5 years). Column (2) shows that the impact of the court order on corrections capital expenditures is observed only during the first 5 years after the order is issued. This result suggests that any capital improvements to the existing prison system take place during the first 5 years. The same pictures emerge in Column (4), where the impact on prison population is observed during the first 5 years. In this specification, the impact of court orders on prison mortality is not significantly different from zero. Table 11 indicates that the impact of a court order on per capita corrections expenditures persists for about 20 years, but that the impact on state cash assistance expenditures is realized during the first 5 years of the court order. When we change the window of coverage to 6 year intervals (i.e., years 1-6, 7-12, etc.), we obtained the same results. The same is true when we use windows that cover 4-year periods. In this case, the impact of court orders on capital expenditures was significant during the first two intervals (8 years).

Our results indicate that court orders have no impact on the expenditure category "Welfare - Cash." We divided this category into two subcategories: payments to private vendors and payments to hospitals and public vendors. The effects of court orders were insignificant for both subcategories. We also divided welfare cash assistance into federal categorical assistance (AFDC/TANF and state SSI) and other cash assistance (general assistance, refugee assistance, home relief, and emergency relief). We found the former category to be impacted by court orders, but not the latter. Finally, adding lagged-dependent variables to the controls produced estimated coefficients that are qualitatively the same (although smaller in magnitude).

We also investigated the impact of court orders on two other indicators of prison conditions: cells per inmate and staff per inmate. The number of cells is partly determined by the structure of the physical facility, and the number of staff per inmate is partly a function of the composition of the inmate population. Nevertheless, these variables are indicators of prison conditions. $^{29}$ Thus, we analyzed whether or not the change in these variables between 1974 and 1990 (the only 2 years in which data are available) was related to the state's litigation status to shed further light into the impact of court orders on prison conditions. The results, displayed in

28. The longest court order duration was in Mississippi with 27 years, followed by New Hampshire with 25 years, and Louisiana and Texas with 23 years (Table 1).

29. There is evidence to indicate that prisoners who are housed in large, open bay dormitories are more likely to visit clinics and to have high blood pressure than are prisoners in other housing arrangements (such as single-bunked cells, double-bunked cells, small dormitories, large-partitioned dormitories). Also, prisons that contain dormitories have somewhat higher assault rates than do other prisons (Gaes 1985). 
Table 10. Impact of Court Orders on Corrections: Models with Staggered Court Order Effects

\begin{tabular}{|c|c|c|c|c|c|}
\hline & $\begin{array}{l}\text { (1) } \\
\text { Corrections } \\
\text { Oper. Exp. } \\
\text { per Inm. }\end{array}$ & $\begin{array}{l}(2) \\
\text { Corrections } \\
\text { Capital Exp. } \\
\text { per Inm. }\end{array}$ & $\begin{array}{l}\text { (3) } \\
\text { Deaths } \\
\text { per Inm. }\end{array}$ & $\begin{array}{l}\text { (4) } \\
\text { Inmates } \\
\text { per Cap. }\end{array}$ & $\begin{array}{l}\text { (5) } \\
\text { Jail } \\
\text { Exp./Cap. }\end{array}$ \\
\hline First 5 years & $\begin{array}{l}0.234^{\star \star \star} \\
(0.065)\end{array}$ & $\begin{array}{c}0.749^{*} \\
(0.394)\end{array}$ & $\begin{array}{c}0.061 \\
(0.156)\end{array}$ & $\begin{array}{c}-0.069^{\star *} \\
(0.032)\end{array}$ & $\begin{array}{c}0.079 \\
(0.090)\end{array}$ \\
\hline Second 5 years & $\begin{array}{l}0.323^{\star \star \star} \\
(0.098)\end{array}$ & $\begin{array}{c}0.519 \\
(0.386)\end{array}$ & $\begin{array}{c}-0.127 \\
(0.188)\end{array}$ & $\begin{array}{r}-0.079 \\
(0.068)\end{array}$ & $\begin{array}{c}0.262 \\
(0.164)\end{array}$ \\
\hline Third 5 years & $\begin{array}{l}0.304^{\star \star} \\
(0.121)\end{array}$ & $\begin{array}{c}0.194 \\
(0.441)\end{array}$ & $\begin{array}{c}0.086 \\
(0.187)\end{array}$ & $\begin{array}{r}-0.010 \\
(0.103)\end{array}$ & $\begin{array}{c}0.322 \\
(0.208)\end{array}$ \\
\hline Fourth 5 years & $\begin{array}{c}0.222^{\star} \\
(0.114)\end{array}$ & $\begin{array}{r}-0.403 \\
(0.634)\end{array}$ & $\begin{array}{c}-0.182 \\
(0.231)\end{array}$ & $\begin{array}{c}0.101 \\
(0.109)\end{array}$ & $\begin{array}{c}0.253 \\
(0.249)\end{array}$ \\
\hline Fifth 5 years & $\begin{array}{c}0.210^{\star} \\
(0.108)\end{array}$ & $\begin{array}{r}-0.492 \\
(0.562)\end{array}$ & $\begin{array}{c}0.049 \\
(0.239)\end{array}$ & $\begin{array}{c}0.001 \\
(0.115)\end{array}$ & $\begin{array}{c}0.254 \\
(0.249)\end{array}$ \\
\hline Income/capita & $\begin{array}{c}0.381 \\
(0.260)\end{array}$ & $\begin{array}{l}4.974^{\star * \star} \\
(1.348)\end{array}$ & $\begin{array}{c}0.767 \\
(0.646)\end{array}$ & $\begin{array}{r}-0.051 \\
(0.178)\end{array}$ & $\begin{array}{l}2.094^{\star * \star} \\
(0.743)\end{array}$ \\
\hline Unemployment rate & $\begin{array}{c}0.002 \\
(0.035)\end{array}$ & $\begin{array}{c}0.140 \\
(0.176)\end{array}$ & $\begin{array}{c}-0.026 \\
(0.074)\end{array}$ & $\begin{array}{c}0.046 \\
(0.031)\end{array}$ & $\begin{array}{l}0.189^{* *} \\
(0.078)\end{array}$ \\
\hline Black (\%) & $\begin{array}{c}0.176 \\
(0.134)\end{array}$ & $\begin{array}{r}-0.262 \\
(0.597)\end{array}$ & $\begin{array}{c}0.045 \\
(0.259)\end{array}$ & $\begin{array}{c}0.078 \\
(0.111)\end{array}$ & $\begin{array}{r}-0.415 \\
(0.385)\end{array}$ \\
\hline Urban (\%) & $\begin{array}{c}-0.912^{\star \star \star} \\
(0.314)\end{array}$ & $\begin{array}{r}-0.602 \\
(1.508)\end{array}$ & $\begin{array}{c}0.387 \\
(0.412)\end{array}$ & $\begin{array}{c}0.994^{\star *} \\
(0.376)\end{array}$ & $\begin{array}{l}2.159^{\star \star} \\
(0.887)\end{array}$ \\
\hline Population 15-24 (\%) & $\begin{array}{c}0.304 \\
(0.316)\end{array}$ & $\begin{array}{c}-0.831 \\
(1.583)\end{array}$ & $\begin{array}{c}0.382 \\
(0.656)\end{array}$ & $\begin{array}{r}-0.426^{\star} \\
(0.245)\end{array}$ & $\begin{array}{r}-0.013 \\
(0.655)\end{array}$ \\
\hline Population 25-44 (\%) & $\begin{array}{r}-0.521 \\
(0.915)\end{array}$ & $\begin{array}{c}-4.800 \\
(3.282)\end{array}$ & $\begin{array}{c}1.297 \\
(1.102)\end{array}$ & $\begin{array}{r}-0.294 \\
(0.594)\end{array}$ & $\begin{array}{c}3.760^{*} \\
(2.023)\end{array}$ \\
\hline Population 45-54 (\%) & $\begin{array}{r}-0.484 \\
(0.374)\end{array}$ & $\begin{array}{l}-2.570 \\
(1.885)\end{array}$ & $\begin{array}{c}0.508 \\
(0.521)\end{array}$ & $\begin{array}{r}-0.043 \\
(0.253)\end{array}$ & $\begin{array}{c}1.329 \\
(1.206)\end{array}$ \\
\hline Population 55 or more (\%) & $\begin{array}{r}-0.534 \\
(0.501)\end{array}$ & $\begin{array}{r}-0.690 \\
(3.018)\end{array}$ & $\begin{array}{c}0.810 \\
(0.887)\end{array}$ & $\begin{array}{c}0.177 \\
(0.465)\end{array}$ & $\begin{array}{c}0.227 \\
(0.970)\end{array}$ \\
\hline Observations & 2,660 & 2,301 & 2,553 & 2,756 & 1,496 \\
\hline$R^{2}$ & 0.956 & 0.458 & 0.443 & 0.976 & 0.947 \\
\hline
\end{tabular}

Notes: The dependent variables are natural logarithms of the corrections operating expenditures per inmate, corrections capital expenditures per inmate, prison deaths per 1000 inmates, prisoners per 1000 residents, and jail expenditures per capita, respectively, in Columns (1-5). All models contain state-fixed effects and year dummies as well as linear and quadratic state trends. Robust standard errors clustered at the state level are presented in parentheses.

Table 12, indicate that the states that came under the court order sometime between 1974 and 1990 (the litigated states) experienced a higher growth rates in cells per inmate and staff per inmate during that time period, indicating that litigated states experienced an improvement in prison conditions relative to nonlitigated states. ${ }^{30}$

30. Given that the average duration of a court order is 18 years, it could be that entrenched bureaucracies and special interests (e.g., prison guards unions, prison contractors) would prevent resources being redistributed back from corrections to cash transfers after a state is released from court order. 


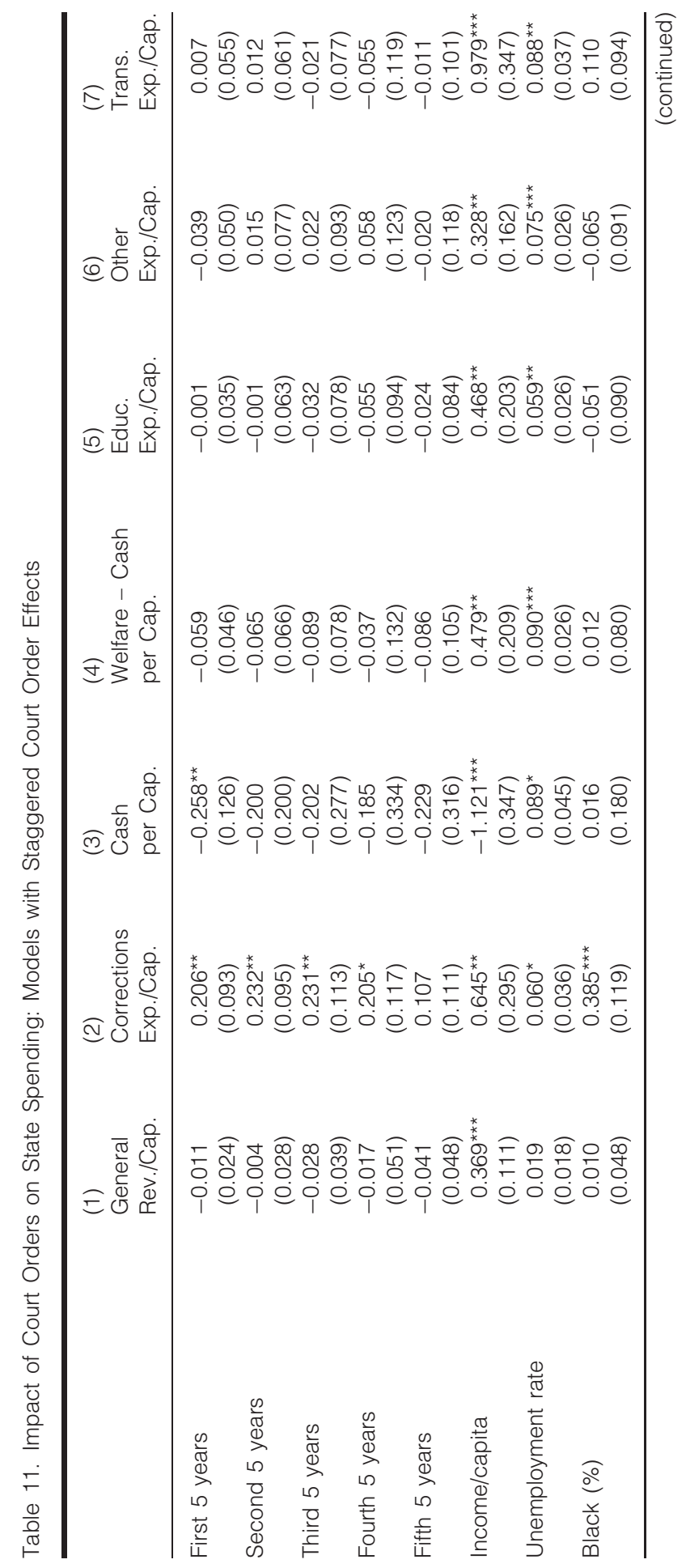




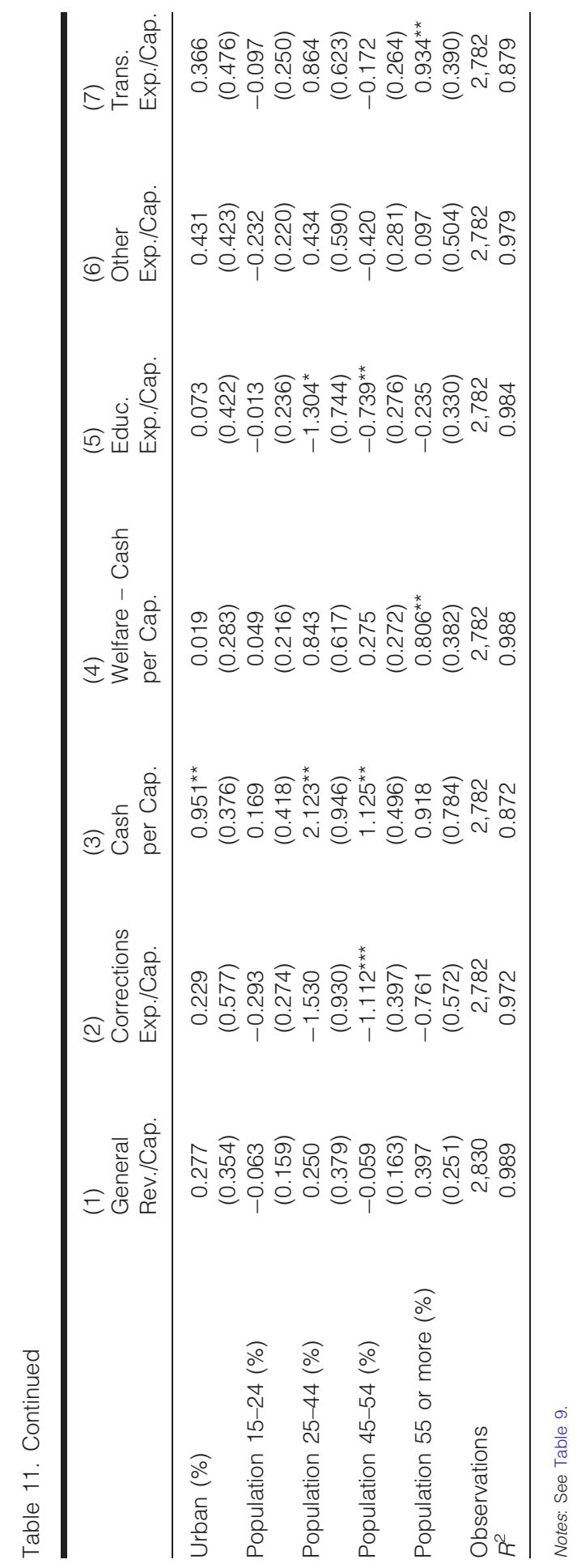

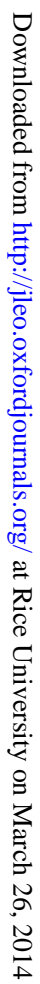


Table 12. Impact of Federal Court Orders on Prison Cells and Prison Staff

\begin{tabular}{|c|c|c|c|c|}
\hline & $\begin{array}{l}(1) \\
\Delta \text { Cells/Inm. }\end{array}$ & $\begin{array}{l}(2) \\
\Delta \text { Cells/Inm. }\end{array}$ & $\begin{array}{l}\text { (3) } \\
\Delta \text { Staff/Inm. }\end{array}$ & $\begin{array}{l}\text { (4) } \\
\Delta \text { Staff/Inm. }\end{array}$ \\
\hline Court order & $\begin{array}{l}0.271^{* *} \\
(0.130)\end{array}$ & $\begin{array}{l}0.209^{* \star *} \\
(0.063)\end{array}$ & $\begin{array}{l}0.138^{\star \star *} \\
(0.038)\end{array}$ & $\begin{array}{l}0.093^{* *} \\
(0.039)\end{array}$ \\
\hline$\Delta$ Income/capita & & $\begin{array}{l}1.416^{\star \star \star} \\
(0.438)\end{array}$ & & $\begin{array}{l}0.454^{\star \star} \\
(0.215)\end{array}$ \\
\hline$\Delta$ Unemp. rate & & $\begin{array}{c}-0.182 \\
(0.129)\end{array}$ & & $\begin{array}{c}0.029 \\
(0.054)\end{array}$ \\
\hline$\Delta$ Black (\%) & & $\begin{array}{l}-0.910^{\star \star \star *} \\
(0.277)\end{array}$ & & $\begin{array}{c}-0.192^{\star *} \\
(0.085)\end{array}$ \\
\hline$\Delta$ Urban (\%) & & $\begin{array}{l}-1.285^{\star \star \star} \\
(0.395)\end{array}$ & & $\begin{array}{c}-0.109 \\
(0.246)\end{array}$ \\
\hline$\Delta$ Population $15-24(\%)$ & & $\begin{array}{c}-0.359 \\
(0.882)\end{array}$ & & $\begin{array}{c}0.211 \\
(0.335)\end{array}$ \\
\hline$\Delta$ Population 25-44 (\%) & & $\begin{array}{c}-1.747 \\
(1.270)\end{array}$ & & $\begin{array}{c}-0.440 \\
(0.687)\end{array}$ \\
\hline$\Delta$ Population 45-54 (\%) & & $\begin{array}{l}2.679^{\star * *} \\
(0.504)\end{array}$ & & $\begin{array}{l}0.649^{\star * *} \\
(0.222)\end{array}$ \\
\hline$\Delta$ Population 55 or more (\%) & & $\begin{array}{l}1.305^{\star \star} \\
(0.640)\end{array}$ & & $\begin{array}{c}0.001 \\
(0.258)\end{array}$ \\
\hline $\begin{array}{l}\text { Observations } \\
R^{2}\end{array}$ & $\begin{array}{c}49 \\
0.084\end{array}$ & $\begin{array}{c}49 \\
0.720\end{array}$ & $\begin{array}{c}49 \\
0.215\end{array}$ & $\begin{array}{c}49 \\
0.584\end{array}$ \\
\hline
\end{tabular}

Notes: The dependent variables are prison cells per inmate in the first two columns and prison guards per inmate in the last two columns. All variables are in natural logarithm differences. Robust standard errors clustered at the state level are presented in parentheses. ${ }^{\star \star *},{ }^{\star \star}$ and ${ }^{*}$ indicate significance at 1,5 , and $10 \%$, respectively.

\section{Conclusion and Discussion}

Federal courts are limited by the Eleventh Amendment of the US constitution, which provides states with immunity. ${ }^{31}$ To get around the Eleventh Amendment, federal cases name-specific state officials as defendants, rather than the state. A recent example is prison litigation filed against California governors Arnold Schwarzenegger and Jerry Brown. However, it is difficult to enforce court orders that require additional spending against state officials since most state constitutions forbid disbursements from the state treasury except by legislative appropriation (Hirschhorn 1984). Furthermore, even if courts could increase prison spending, such additional spending could have detrimental effects if it leads to cuts in welfare programs.

In this article, we employ a state-level panel data set from 1951 to 2006 to investigate states' reactions to federal court interventions. Specifically, we analyze the impact of court orders on prison spending, prison conditions, per capita prisoners, as well as state spending on welfare, education,

31. For instance, in 1973, the US Supreme Court reversed a US district court school equalization order, effectively removing the federal courts from school finance litigation (San Antonio Independent School District v. Rodriguez, 411 US 1, 1973). 
transportation, and other state spending. We find that court intervention in state prisons increased per inmate operating expenditures by about $27 \%$, doubled per capita corrections capital expenditures, decreased prisoners per capita by $12 \%$, and prison mortality by six prisoner deaths per year.

We also investigate the effect of the release from a court order, and we find no evidence of decreases in expenditures on corrections after court orders are lifted. Similarly, the prison mortality rate does not change following the release from court order.

Since court orders make it more expensive for states to deter crime through imprisonment, one could expect states to shift toward relatively cheaper means of deterring crime. For example, given that spending on education and welfare programs is expected to negatively impact criminal activity, states could spend more on these budget items following the imposition of court orders. However, we find that following court orders, state expenditures on education, transportation, and other items remained the same, but expenditures related to welfare spending on cash assistance decreased by about $22 \%$. We cannot reject the hypothesis that the decline in cash assistance payments equals the increase in correctional expenditures. In addition, our results indicate that after the state has been released from court order, spending on cash payments is not restored.

One explanation of these finding is that welfare is the first budget item for the states to cut when a budget shortfall is faced. Regardless of the mechanism that generates this outcome, the findings underscore that states shift the burden of increased correctional spending on welfare recipients. This suggests that courts should follow Brown v. Plata and take into account the unintended consequences of increased prison spending, namely, cuts in welfare spending.

\section{References}

Angrist, Joshua D., and Victor Lavy. 2001. "Does teacher training affect pupil learning? Evidence from matched comparisons in Jerusalem Public Schools," 19 Journal of Labor Economics 343-69.

Ashenfelter, Orley, and David Card. 1985. "Using the Longitudinal Structure of Earnings to Estimate the Effect of Training Programs," 67 The Review of Economics and Statistics 648-60.

Baicker, Katherine. 2001. "Government Decision-making and the Incidence of Federal Mandates," 82 Journal of Public Economics 147-94.

Baicker, Katherine, and Nora Gordon. 2006. "The Effect of State Education Finance Reform on Total Local Resources," 90 Journal of Public Economics 1519-35.

Berry, William D., Evan J. Ringquist, Richard C. Fording, and Russell L. Hanson. 1998. "Measuring Citizen and Government Ideology in the American States, 1960-93," 42 American Journal of Political Science 327-48.

Biderman, Ciro, João M. P. De Mello, and Alexander Schneider. 2010. "Dry Laws and Homicides: Evidence from the São Paulo Metropolitan Area," 120 Economic Journal 157-82.

Bleich, Jeff. 1989. "The Politics of Prison Crowding," 77 California Law Review 1125-80. 
Card, David, and Abigail Payne. 2002. "School Finance Reform, the Distribution of School Spending, and the Distribution of Student Test Cores," 83 Journal of Public Economics 49-82.

Cameron, A. Colin, Jonah H. Gelbach, and Douglas L. Miller. 2008. "Bootstrap-based Improvements for Inference With Clustered Errors," 90 The Review of Economics and Statistics 414-27.

Corman, Hope, and H. Naci Mocan. 2000. "A Time-series Analysis of Crime and Drug Use in New York City," 90 American Economic Review 584-604.

- 2005. "Carrots, Sticks and Broken Windows," 48 Journal of Law and Economics 235-66.

Donohue, John J., and Peter Siegelman. 1998. "Allocating Resources Among Prisons and Social Programs in the Battle Against Crime," 27 Journal of Legal Studies 1-43.

Donohue, John J., and Justin Wolfers. 2005. "Uses and Abuses of Empirical Evidence in the Death Penalty Debate," 58 Stanford Law Review 791-846.

Drago, Francesco, Roberto Galbiati, and Pietro Vertova. 2009. "The Deterrent Effects of Prison: Evidence from a Natural Experiment," 117 Journal of Political Economy 257-80.

Fliter, John. 1996. "Another Look at the Judicial Power of the Purse: Courts, Corrections, and State Budgets in the 1980s," 30 Law \& Society Review 399-416.

Freeman, Richard. 1984. "Longitudinal Analyses of the Effects of Trade Unions," 2 Journal of Labor Economics 1-26.

Gaes, Gerald G. 1985. "The Effects of Overcrowding in Prison," 6 Crime and Justice 95-146.

Gould, Eric D., David B. Mustard, and Bruce A. Weinberg. 2002. "Crime Rates and Local Labor Market Opportunities in the United States: 1977-1997," 84 Review of Economics and Statistics 45-61.

Harriman, Linda, and Jeffrey D. Straussman. 1983. "Do Judges Determine Budget Decisions? Federal Court Decisions in Prison Reform and State Spending for Corrections," 43 Public Administration Review 343-51.

Hirschhorn, James M. 1984. "Where the Money is: Remedies to Finance Compliance with Structural Injunctions," 82 Michigan Law Review 1815-77.

Katz, Lawrence, Steven D. Levitt, and Ellen Shustorovich. 2003. "Prison Conditions, Capital Punishment, and Deterrence," 5 American Law and Economics Review 318-43.

Kennedy, Peter E. 1981. "Estimation with Correctly Interpreted Dummy Variables in Semilogarithmic Equations," 71 American Economic Review 801.

Levitt, Steven D. 1996. "The Effect of Prison Population Size on Crime Rates: Evidence from Prison Overcrowding Litigation," 111 The Quarterly Journal of Economics 319-51.

Lin, Ming-Jen. 2008. "Does Unemployment Increase Crime? Evidence from U.S. Data 19742000," 43 Journal of Human Resources 413-36.

Lochner, Lance, and Enrico Moretti. 2004. "The Effect of Education on crime: Evidence from Prison Inmates, Arrests, and Self-reports," 94 American Economic Review 155-89.

Lutz, Byron. 2011. "The End of Court-Ordered Desegregation," 3 American Economic Journal: Economic Policy 130-68.

Mocan, H. Naci, and Turan Bali. 2010. "Asymmetric Crime Cycles," 92 The Review of Economics and Statistics 899-911.

Murray, Sheila, William N. Evans, and Robert M. Schwab. 1998. "Education-Finance Reform and the Distribution of Education Resources," 88 The American Economic Review 789-812.

Piehl, Anne Morrison, and Margo Schlanger. 2004. "Determinants of Civil Rights Filings in Federal District Court by Jail and Prison Inmates," 1 Journal of Empirical Legal Studies 79-109.

Rose-Ackerman, Susan. 2003. "Book Review. Democracy by Decree: What Happens When Courts Run Government," 118 Political Science Quarterly 679-81.

Roth, John Herbert. 2003. "Education Funding and the Alabama Example: Another Player on a Crowded Field," B.Y.U. Education Law Journal 739-66.

Sandler, Ross, and David Schoenbrod. 2004. "The Supreme Court, Democracy and Institutional Reform Litigation," 49 NYU Law Review 915-42. 
Schlanger, Margo. 1999. "Beyond the Hero Judge: Institutional Reform Litigation as Litigation," 97 Michigan Law Review 1994-2036.

—. 2006. "Civil Rights Injunctions Over Time: A Case Study of Jail and Prison Court Orders," 81 New York University Law Review 550-630.

Sullivan, John. 2000. "States and Cities Removing Prisons from Courts' Grip,"New York Times, January 30, P1.

Taggart, William A. 1989. "Redefining the Power the Federal Judiciary: The Impact of Court-ordered Prison Reform on State Expenditures for Corrections," 23 Law \& Society Review 241-71.

Wharton, Joseph. 1996. "Courts Now Out of Job as Jailers," 82 ABA Journal 40.

Wood, B. Dan, and Nick A. Theobald. 2003. "Political Responsiveness and Equity in Public Education Finance," 65 Journal of Politics 718-38. 